\title{
Pengaruh Model Discovery Learning Berbantuan Lingkungan Terhadap Kompetensi Pengetahuan IPA Siswa Kelas V
}

\author{
Ni M.C.D.Putri1 ${ }^{*}$, IK. Ardana², G.N.S. Agustika ${ }^{3}$ \\ 1,2,3 Jurusan Pendidikan Guru Sekolah Dasar, Universitas Pendidikan Ganesha, Singaraja, Indonesia
}

\section{ARTICLEIN \\ $\mathrm{FO}$ Article history: Received 12 May 2018 \\ Received in revised form \\ 18 June 2018 Accepted 16 July 2018 \\ Available online 28 \\ August 2018

Kata Kunci:
model discovery
learning, lingkungan,
kompetensi
pengetahuan IPA
.Keywords:
discovery learning
model, environment,
science knowledge
competence

\begin{abstract}
A B STRAK
Penelitian ini bertujuan untuk mengetahui pengaruh model discovery learning berbantuan lingkungan terhadap kompetensi pengetahuan IPA siswa kelas V SD Negeri Gugus II Kuta Utara Tahun Ajaran 2017/2018. Penelitian ini merupakan quasi-experiment dengan desain non-equivalen. Populasi pada penelitian ini adalah 10 kelas $\mathrm{V}$ dengan jumlah 334 siswa. Sampel penelitian diperoleh dengan teknik simple random sampling, diperoleh kelas V SD No. 3 Tibubeneng sebagai kelompok eksperimen dan kelas $V_{C}$ SD No. 2 Tibubeneng sebagai kelompok kontrol. Metode yang digunakan dalam penelitian ini adalah metode tes dengan tes pilihan ganda biasa. Data yang dikumpulkan adalah data kompetensi pengetahuan IPA dan dianalisis menggunakan uji-t. Analisis yang digunakan dalam menguji hipotesis adalah uji-t, diperoleh $t$ hitung yaitu 3,926. $t$ hitung tersebut dibandingkan dengan $t_{\text {tabel }}$ pada taraf signifikansi $5 \%$ dan $\mathrm{dk}=63$ diperoleh $\mathrm{t}$ tabel $=1,998$. Berdasarkan kriteria pengujian, diperoleh $t$ hitung $>t$ tabel yaitu $3,926>1,998$, maka $\mathrm{H}_{0}$ ditolak, berarti terdapat perbedaan yang signifikan kompetensi pengetahuan IPA kelompok siswa yang dibelajarkan melalui model discovery learning berbantuan lingkungan dan kelompok siswa yang dibelajarkan melalui pembelajaran konvensional pada kelas V SD Negeri Gugus II Kuta Utara Tahun Ajaran 2017/2018. Dapat dikatakan bahwa
\end{abstract} terdapat pengaruh yang signifikan model discovery learning berbantuan lingkungan terhadap kompetensi pengetahuan IPA siswa kelas V SD Negeri Gugus II Kuta Utara Tahun Ajaran 2017/2018. Untuk penelitian yang memiliki kesamaan variabel, hasil penelitian ini dapat dipergunakan sebagai kajian penelitian relevan.

\section{A B S T R A C T}

This study aims to determine the effect of environmentally-assisted discovery learning model toward science knowledge competence of grade V students of SD Negeri Gugus II Kuta Utara in the academic year 2017/2018. This research is a quasi-experiment with non-equivalent design. The population in this study is 10 class $V$ with total 334 students. The sample of the research was obtained by simple random sampling technique, obtained by class V SD No. 3 Tibubeneng as experimental group and class VC SD No. 2 Tibubeneng as a control group. The method used in this research is the test method with the usual double choice test. The data collected were science knowledge competence data and analyzed using t-test. The analysis used in testing the hypothesis is t-test, obtained $t$ arithmetic is 3.926. $t$ arithmetic compared with $t$ table at $5 \%$ significance level and $\mathrm{dk}=63$ obtained $t$ table $=1.998$. Based on the test criteria, obtained $t$ count $>t$ table that is $3.926>1.998$, then $\mathrm{Ho}$ is rejected, it means there is a significant difference of knowledge competence of science group of students who learned through environmentally-assisted discovery learning model and group of students that is learned through conventional learning in class V SD Negeri Cluster II of Kuta Utara Academic Year 2017/2018. It can be said that there is a significant influence of environmentallyassisted discovery learning model toward science knowledge competence of grade $\mathrm{V}$ students of SD Negeri Gugus II Kuta Utara in the academic year 2017/2018. For research that has a similarity of variables, the results of this study can be used as relevant research studies.

Copyright (C) Universitas Pendidikan Ganesha. All rights reserved.

\footnotetext{
*orresponding author.

E-mail addresses: canessiaputri@gmail.com (Ni Made Canessia Putri)
} 


\section{Pendahuluan}

Pendidikan dan manusia adalah hal yang tidak bisa dipisahkan karena saling terkait. Pendidikan sangat penting demi menunjang kehidupan manusia. Manusia dibekali pikiran dan akal untuk menjalani kehidupan, dengan pikiran dan akal yang dimiliki melalui pendidikan manusia dapat berkembang dan menambah pengetahuannya. Pendidikan merupakan sarana yang dilalui peserta didik untuk mengembangkan potensi diri yang sesuai dengan tujuan pendidikan. Pendidikan yang ditempuh ada pendidikan formal dan nonformal, dimana pendidikan formal seperti sekolah sedangkan pendidikan nonformal seperti bimbingan belajar, taman bermain, kursus musik dan pendidikan yang di luar pendidikan formal. Maka perlunya pendidikan bagi semua orang agar memperoleh manusia yang berkualitas.

Mutu pendidikan khususnya di Indonesia terus dikembangkan dan dievaluasi oleh pemerintah dan tenaga pengajar. Salah satu upaya yang dilakukan yaitu pengembangan kurikulum. Saat ini, kurikulum yang diterapkan di Indonesia adalah kurikulum 2013 atau K13. Kurikulum ini memiliki 4 aspek yang meliputi aspek pengetahuan, aspek keterampilan, aspek perilaku dan aspek sikap. Dalam kurikulum 2013, pengembangan materi-materi yang dulu dirancang 1 mata pelajaran dikembangkan menjadi materimateri terintegrasi dan terpadu dalam suatu tema yang disebut tematik terpadu. Kurikulum 2013 dalam Permendikbud Nomor 57 Tahun 2014, IPA bukan lagi merupakan bidang studi namun sebagai muatan pelajaran yang diintegrasikan ke mata pelajaran lain. Kurikulum 2013 yang mengusung pembelajaran yang terpadu antara materi-materi dari berbagai bidang studi, yang dimana IPA menjadi salah satunya. Ilmu pengetahuan alam, yang sering disebut juga dengan istilah pendidikan sains, disingkat menjadi IPA. Menurut Usman (2016) IPA atau science merupakan ilmu yang mempelajari aspek-aspek yang ada di alam baik itu komponen atau interaksi yang terjadi. Ilmu pengetahuan alam merupakan terjemahan kata-kata dalam bahasa Inggris yaitu natural science, artinya Ilmu Pengetahuan Alam (IPA). "IPA atau sains merupakan ilmu yang terkonstruksi baik secara personal maupun sosial" (Wisudawati dan Eka, 2014 : 8). Jadi ilmu pengetahuan alam (IPA) atau science adalah ilmu yang mempelajari peristiwa-peristiwa yang terjadi di alam ini yang terkonstruksi dengan baik secara personal atau sosial. IPA merupakan salah satu mata pelajaran pokok dalam kurikulum pendidikan di Indonesia, termasuk pada jenjang sekolah dasar.

Keterpaduan yang telah dirancang oleh pemerintah untuk menjadikan pendidikan dan pemahaman terhadap pembelajaran menjadi lebih baik dan bermakna. Penguasaan kompetensi IPA masih kurang optimal karena masih dianggap sulit bagi sebagian peserta didik. Kurang optimalnya penguasaan kompetensi khususnya IPA dikarenakan pengajaran yang dilakukan oleh guru kurang memberi pemahaman kepada peserta didik. Rancangan pembelajaran yang dirancang oleh guru harus sesuai dengan karakteristik peserta didik agar tercapai tujuan pembelajaran.

Pembelajaran merupakan cara atau rencana yang telah disusun untuk membantu peserta didik dalam belajar dan berkembang sesuai tujuan yang telah disusun (Budiman, 2012). Hasil observasi yang dilakukan pada tanggal 4 dan 5 Januari 2018 di SD Negeri Gugus II Kuta Utara pembelajaran yang masih berpusat pada guru sehingga siswa masih pasif dalam pembelajaran. Pembelajaran masih berpusat pada guru yang hanya memberikan teori sehingga pengetahuan yang dimiliki siswa kurang optimal khususnya pada muatan materi IPA. Hal tersebut diperkuat dengan hasil kompetensi pengetahuan IPA siswa yang diambil dari hasil nilai semester 1 (ganjil) menunjukan hasil nilai kompetensi pengetahuan IPA beberapa siswa masih dibawah KKM yaitu 75. Berdasarkan data yang diperoleh dari 334 siswa, 186 siswa atau 55, $68 \%$ yang sudah mencapai KKM dan 148 siswa atau $44,32 \%$ yang belum mencapai KKM. Banyak hal yang dapat dilakukan oleh guru seperti menerapkan metode, strategi atau model pembelajaran untuk memvariasikan cara mengajar, salah satunya penggunaan model dalam mengajar. Penggunaan model pembelajaran dapat memberikan kreasi dan inovasi baru dalam pengajaran di kelas sehingga memberikan suasana baru untuk siswa. Sebagai seorang guru dituntut untuk kreatif dan inovatif dalam pembelajaran. Banyak hal yang dapat dilakukan oleh guru seperti menerapkan metode, strategi atau model pembelajaran untuk memvariasikan cara mengajar, salah satunya penggunaan model dalam mengajar. Penggunaan model pembelajaran dapat memberikan kreasi dan inovasi baru dalam pengajaran di kelas sehingga memberikan suasana baru untuk siswa.

Salah satu model pembelajaran yang dapat diterapkan adalah model discovery learning. (Sani, 2014:97) discovery learning merupakan model dimana siswa menemukan sendiri konsep yang melalui serangkaian data atau informasi yang diperoleh melalui pengamatan atau percobaan). Penggunaan model ini dapat membantu dan membimbing siswa memperoleh pengetahuaanya sendiri dan siswa lebih memahami. Dalam penerapan model discovery learning guru tidak diam tetapi menjadi fasilitator dan pembimbing bagi siswa dalam menemukan pengetahuannya atau memecahkan masalah yang diberikan. Penggunaan model pembelajaran akan lebih optimal dengan bantuan media pembelajaran atau sumber belajar. Salah satu sumber belajar atau media adalah lingkungan. 
Husamah (2013) menjelaskan bahwa lingkungan merupakan seluruh komponen yang ada di alam sekitar termasuk manusia, hewan dan tumbuhan serta interaksi yang terjadi di dalamnya. Pengunaan bantuan lingkungan baik sebagai sumber belajar atau media sangat efektif dan efisien, karena tidak memerlukan biaya yang cukup besar. Perpaduan antara model discovery learning berbantuan lingkungan dapat optimal dengan cara mengajar guru yang mengaitkan materi pembelajaran dengan lingkungan sekitar siswa. Penguasaan kompetensi pengetahuan siswa khususnya IPA dapat menjadi lebih optimal dengan cara guru mengajar, memilih model pembelajaran dan sumber belajar atau media yang sesuai dengan materi serta karakteristik peserta didik. Sehingga Lingkungan sebagai media pembelajaran dalam penunjang atau membantu model pembelajaran discovery learning memberikan peluang yang sangat besar untuk peserta didik menambah pengetahuan dan mengasah kemampuannya serta mencapai tujuan pembelajaran dan memotivasi peserta didik dalam belajar.

Berdasarkan uraian yang telah dipaparkan, maka judul yang diangkat adalah Pengaruh Model Discovery Learning Berbantuan Lingkungan Terhadap Kompetensi Pengetahuan IPA Siswa Kelas V SD Negeri Gugus II Kecamatan Kuta Utara Tahun Ajaran 2017/2018.

\section{Metode}

Pelaksanaan penelitian dila-kukan di SD Gugus II Kuta Utara. Waktu penelitian terkait dengan penelitian ini dilaksanakan selama 2 bulan mulai Maret sampai dengan April 2018, perlakuan sebanyak 6 kali di kelompok eksperimen dan 6 kali di kelompok kontrol. Jumlah perlakuan yang diberikan telah disesuaikan dengan jam pelajaran terkait materi dalam penelitian ini yang telah diatur dalam kurikulum.

Jenis penelitian yang diguna-kan adalah eksperimen semu (quasi experiment). Penelitian eksperimen semu ini membandingkan dua jenis pembelajaran model discovery learning berbantuan lingkungan dengan pembelajaran konvensional, yang mana kedua pembelajaran tersebut mempunyai pengaruh terhadap satu variabel terikat (Kompetensi). Hal ini dikarenakan kemampuan peneliti dalam mengamati perilaku siswa sangat terbatas terutama ketika siswa ber-ada di luar sekolah (rumah), peneliti juga tidak memiliki kemampuan untuk mengetahui persepsi siswa terhadap perlakuan secara pasti. Desain eksperimen yang digunakan adalah "nonequivalent". Pada desain ini kedua kelompok yang akan diteliti diberikan pretest dan posttest. Pretest digunakan untuk penyetaraan kelompok. Teknik yang digunakan dalam peyetaraan kelompok adalah dengan menggunakan uji-t. Setelah itu peneliti memberikan perlakuan, yaitu dengan menerapkan modeldiscovery learning berbantuan lingkungan kepada kelompok eksperimen, dan pembelajaran konvensionalpada kelas kontrol.

Populasi merujuk pada keseluruhan kelompok dari mana sempel-sampel akan diambil" (Setyosari, 2015:220). Selanjutnya, Sugiyono (2016:80) memaparkan bahwa populasi adalah wilayah generalisasi yang terdiri atas: objek atau subjek yang mempunyai kualitas atau karakteristik tertentu yang ditetapkan oleh peneliti untuk dipelajari dan kemudian ditarik kesimpulannya. Lebih lanjut, Agung, A. (2014:69) menjelaskan populasi merupakan keseluruhan objek dalam suatu penelitian. Jadi, populasi penelitian adalah keseluruhan kelompok yang terdiri atas objek atau subjek dari mana sampel-sampel akan diambil untuk dijadikan sumber data dalam penelitian. Populasi penelitian ini adalah 10 kelas V SD Gugus II Kuta Utara tahun pelajaran 2017/2018 yang berjumlah 334siswa. Dari populasi tersebut dapat diambil sampel yang mewakili karakteristik dari populasi yang ditelliti. Menurut Sugiyono (2016:81) sampel adalah bagian jumlah karakteristik yang dimiliki oleh populasi tersebut. Lebih lanjut, Setyosari (2015:221) memaparkan sampel adalah suatu kelompok yang lebih kecil atau bagian dari populasi secara keseluruhan. Jadi, sampel adalah suatu kelompok kecil dari populasi yang dijadikan subjek atau objek penelitian dengan jumlah karakteristik yang dimiliki populasi tersebut.

Kegunaan sampel dimaksudkan bila terdapat populasi yang besar dan peneliti tidak mungkin mempelajari semua yang ada pada populasi, maka peneliti dapat men ggunakan sampel yang diambil dari populasi. Kesimpulan yang dipelajari pada sampel dapat diberlakukan untuk populasi, sehingga sampel yang diambil dari populasi harus betul-betul representatif (mewakili).Teknik pengambilan sampel pada penelitian ini dilakukan dengan cara teknik simple random sampling, karena dalam penelitian ini dipilih 2 kelas yang dijadikan subjek penelitian. Terdapat sebanyak 10 kelas V yang terdiri dari 7 SD di Gugus II Kuta Utara. Setelah mendapatkan 2 kelas yang diperoleh dari hasil random sampel kelompok, maka selanjutnya 2 kelas yang terpilih diberikan pretest. Pretest yang diberikan untuk menyetarakan kelompok. Penyetaraan kelompok dilakukan dengan uji-t. data nilai pretest kedua kelompok dianalisis dengan menggunakan uji-t. Kriteria kesetaraan dengan uji-t jika $t_{\text {hitung }}<t_{\text {tabel, }}$ jadi kedua kelompok itu dinyatakan setara. Kedua sampel yang didapatkan yaitu SD No. 3 Tibubeneng dan SD No. 2 Tibubeneng diberikan pretest dan melalukan analisis uji-t untuk penyetaraan kelompok. Setelah kedua kelompok tersebut setara maka diundi untuk menentukan kelompok eksperimen dan kelompok kontrol. Hasil undian tersebut didapatkan SD No. 3 Tibubeneng sebagai kelompok eksperimen dan SD No. 2 Tibunebeng sebagai 
kelompok kontrol. Kelompok eksperimen akan diberikan perlakukan dengan model discovery learning berbantuan lingkungan dan kelompok kontrol dibelajarkan melalui pembelajaran konvensional.

Data yang dikumpulkan dalam penelitian ini adalah data kompetensi pengetahuan IPA siswa kelas V SD Gugus II Kuta Utara Tahun ajaran 2017/2018. Teknik pengumpulan data pada penelitian ini adalah metode tes. Kegiatan pengumpulan data dilaksanakan pada siswa kelas V SD di SD Gugus II Kuta Utara Tahun ajaran 2017/2018 yang menjadi anggota sampel. Data tentang kompetensi pengetahuan IPA. Menurut Arikunto (2015), Tes adalah alat atau prosedur yang digunakan untuk mengukur atau mengetahui sesuatu.Tes yang akan digunakan untuk mengukur kompetensi pengetahuanIPA berupa tes objektif dalam bentuk pilihan ganda biasa. Test yang akan digunakan harus diuji cobakan terlebih dahulu untuk ketepatan dalam penggunaan instrumen test tersebut. Instrumen test terlebih dahulu di uji ahli oleh para ahli pada bidangnya dimana penelitian ini terkait dengan kompetensi pengetahuan IPA, maka ahli pada bidangnya atau yang berkompeten. Selanjutnya setelah uji ahli maka dilakukan uji instrumen test yaitu Adapun langkah-langkah yang dilakukan dalam menyusun instrumen tes kompetensi pengetahuan IPA, yakni: 1) mengidentifikasi kompetensi inti dan kompetensi dasar, 2) mrngidentifikasi indikator pencapaian siswa, 3) menyusun kisi-kisi tes hasil belajar, 4) menyusun butir-butir tes, 5) revisi butir tes, 6) finalisasi instrumen. Sebelum tes tersebut digunakan, terlebih dahulu tes diuji validitas, reliabilitas, daya beda dan indeks kesukaran.

Rancangan penelitian yang digunakan dalam penelitian ini adalah kuantitaif dengan menggunakan uji-t sebagai alat untuk menganalisis data. Deskripsi data hasil kompetesnsi pengetahuan IPA siswa yang dipaparkan meliputi nilai rata-rata, variansi, dan standar deviasi.

\section{Hasil dan Pembahasan}

Kelas V SD No. 3 Tibubeneng ditetapkan sebagai kelompok eksperimen yang diberi perlakuan berupa pengaruh model discovery learning berbantuan lingkungan sebanyak 6 kali pertemuan, selanjutnya diberikan posttest untuk memeroleh hasil kompetensi pengetahuan IPA.

Nilai mean atau rata-rata kom-petensi pengetahuan IPA siswa yang dibelajarkan melalui model discovery learning berbantuan lingkungan, yaitu $\bar{X}=84,63$ dengan variansi 111,73 dan standar deviasi $(s=10,57)$, sedangkan nilai mean atau rata-rata kompetensi pengetahuan IPA siswa yang dibelajarkan melalui pembelajaran konvensional , yaitu $\bar{X}=74,03$ dengan variansi 124,91 dan standar deviasi (s=11,18). Rekapitulasi hasil data posttest

Perhitungan analisis data hasil penelitian yang diperoleh menun-jukkan bahwa kompetensi pengetahuan IPA kelompok eksperimen yakni siswa yang mengikuti pembelajaran menggunakan model discovery learning berbantuan lingkungan memiliki nilai mean lebih tinggi daripada kelompok kontrol yaitu $\bar{X}=84,63>\bar{X}=74,03$.

Uji prasyarat dilakukan ter-lebih dahulu sebelum uji hipotesis menggunakan uji-t. Uji prasyarat tersebut meliputi uji normalitas dan uji homogenitas variansi diuraikan ber-ikut ini.

Uji normalitas dilakukan untuk mengetahui sebaran frekuensi skor, untuk menguji data kompetensi pengetahuan IPA kelompok eksperimen dan kontrol adalah metode kolmogorov-smirnov. Kriteria pengujian pada uji normalitas adalah jika nilai maksimum $\left|\mathrm{F}_{\mathrm{T}}-\mathrm{F}_{\mathrm{S}}\right| \leq$ nilai table kolmogorov-smirnovmaka sebaran data kedua kelompok berdistribusi normal. Berdasarkan hasil uji normalitas kelompok eksperimen, diperoleh nilai maksimum $\left|\mathrm{F}_{\mathrm{T}}-\mathrm{F}_{\mathrm{S}}\right|=0,131$ kemudian nilai tersebut dibandingkan dengan nilai tabel kolmogorov-smirnov dengan taraf signifikan $5 \%$ dk 32 yaitu 0,234 . Hal ini menunjukkan bahwa nilai maksimum $\left|\mathrm{F}_{\mathrm{T}}-\mathrm{F}_{\mathrm{S}}\right|<$ nilai tabel kolmogorov-smirnov berarti data hasil kompetensi pengetahuan IPA kelompok ekspe-rimen berdistribusi normal. Berdasarkan hasil uji normalitas kelompok kontrol, diperoleh nilai maksimum $\left|\mathrm{F}_{\mathrm{T}}-\mathrm{F}_{\mathrm{S}}\right|=0,098$ kemudian nilai tersebut dibandingkan dengan nilai tabel kolmogorov-smirnov dengan taraf signifikan $5 \%$ dk 33 yaitu 0,231 . Hal ini menunjukkan bahwa nilai maksimum $\mid F_{T}-F_{S}<$ nilai tabel kolmogorov-smirnov berarti data hasil kompetensi pengetahuan IPA kelompok kontrol berdistribusi normal.

Pengujian homogenitas variansi antar kelompok dimaksudkan untuk meyakinkan bahwa perbedaan yang diperoleh uji-t benar-benar berasal dari perbedaan antar kelompok bukan disebabkan oleh perbedaan di dalam kelompok. Uji homogenitas variansi yang dilakukan dalam pene-litian ini menggunakan uji F. Dari hasil analisis, diperoleh $\mathrm{F}_{\text {hitung }}=1,12$ dan $\mathrm{F}_{\text {tabel }}=1,80$. Hal ini berarti $\mathrm{F}_{\text {hitung }} \leq \mathrm{F}_{\text {tabel }}$, sehingga data kedua kelompok memiliki variansi yang homogen. Berdasarkan hasil uji prasyarat yang terdiri dari uji normalitas dan uji homogenitas varians, disimpulkan bahwa data kedua kelompok sampel ialah berdistribusi normal dan me-miliki variansi yang homogen. Dengan demikian, uji hipotesis menggunakan uji-t dapat dilakukan. 
Hipotesis yang diuji dalam pe-nelitian ini adalah tidak terdapat perbedaan yang signifikan kompetensi pengetahuan IPA antara siswa kelas V SD Gugus II Kuta Utara tahun pelajaran 2017/2018yang dibelajarkan menggunakanmodel discovery learning berbantuan lingkungan dan siswa yang dibelajarkan melalui pembelajaran konvensional.

Hasil uji prasyarat yang me-liputi uji normalitas dan homogenitas variansi yang dilakukan dalam pe-nelitian ini diperoleh kedua kelompok sampel berdistribusi normal dan memiliki variansi yang homogen. Analisis statistik yang digunakan untuk menguji hipotesis penelitian ini adalah uji-t dengan polled varians. Berdasarkan hasil perhitungan uji-t, diperoleh $t_{\text {hitung }}=3,926$ dan untuk taraf signifikansi $5 \%$ dengan $\mathrm{dk}=(32+33-2)=63$ diperoleh $t_{\text {tabel }}=1,998$. Dengan demikian, nilai $t_{\text {hitung }}>t_{\text {tabelyakni }} 3,926>1,998$ sehingga $\mathrm{H}_{0}$ ditolak. $\mathrm{H}_{\mathrm{o}}$ dalam penelitian ini adalah tidak terdapat perbedaan yang signifikan kompetensi pengetahuan IPA antara kelompok siswa yang dibelajarkan melalui model discovery learning berbantuan lingkungan dan kelompok siswa yang dibelajarkan melalui pembelajaran konvensional siswa kelas $\mathrm{V}$ di Gugus II Kuta Utara Tahun Pelajaran 2017/2018.

Perhitunganrekapitulasi hasil analisis uji-t kelompok sampel peneli-tian ini disajikan dalam tabel berikut.

Tabel Rekapitulasi Hasil Analisis Data Kompetensi Pengetahuan IPA Menggunakan Uji-t

\begin{tabular}{|c|c|c|c|c|c|c|c|c|}
\hline No & Sampel & $\mathrm{N}$ & $\mathrm{Dk}$ & $\bar{X}$ & $\mathrm{~S}^{2}$ & $t_{\text {hitung }}$ & $t_{\text {tabel }}$ & Status \\
\hline 1 & $\begin{array}{l}\text { Kelompok } \\
\text { eksperimen }\end{array}$ & 32 & \multirow{2}{*}{63} & 84,63 & 111,73 & \multirow{2}{*}{3,926} & \multirow{2}{*}{1,998} & \multirow{2}{*}{$\begin{array}{l}\mathrm{H}_{0} \\
\text { ditolak }\end{array}$} \\
\hline 2 & $\begin{array}{l}\text { Kelompok } \\
\text { kontrol }\end{array}$ & 33 & & 74,03 & 124,91 & & & \\
\hline
\end{tabular}

Berdasarkan uji hipotesis di-peroleh $t_{\text {hitnung }}=3,926$ sedangkan pa-da taraf signifikansi $5 \%$ dan dk= 63 diperoleh nilai $t_{\text {tabel }}=1,998$ sehingga $t_{\text {hitnung }}=3,926>t_{\text {tabel }}=1,998$. Dengan demikian, hipotesis nol $H_{0}$ di tolak yang menyatakan bahwa tidak terdapat perbedaan yang signifikan kompetensi pengetahuan IPA kelompok siswa yang dibelajarkan melalui model discovery learning berbantuan lingkungan dan kelompok siswa yang dibelajarkan melalui pembelajaran konvensionalpada kelas V sekolah dasar Negeri Gugus II Kuta Utara tahun pelajaran 2017/2018 dan $\mathrm{H}_{a}$ diterima yang menyatakan bahwa terdapat perbedaan yang signifikan kompetensi pengetahuan IPA kelompok siswa yang dibelajarkan melalui model discovery learning berbantuan lingkungan dan kelompok siswa yang dibelajarkan melalui pembelajaran konvensionalpada kelas V sekolah dasar Gugus II Kuta Utara tahun pelajaran 2017/2018. Hal ini berarti terdapat pengaruh model discovery learning berbantuan lingkunganterhadap kompetensi pengetahuan IPA siswa kelas V SD Gugus II Kuta Utara tahun ajaran 2017/2018.

Perolehan hasil perhitungan analisis data yang dilakukan menun-jukkan bahwa nilai rata-rata siswa yang dibelajarkan melalui model discovery learning berbantuang lingkungan $(\bar{X}=84,63)$ dengan perolehan nilai terendah 66 dan nilai tertinggi 100, sesuai dengan analisis nilai kompetensi pengetahuan IPA siswa pada kelompok eksperimen. Hasil rata-rata siswa yang dibelajarkan melalui pembelajaran konvensional $(\bar{X}=74,03)$ dengan perolehan nilai terendah 59 dan nilai tertinggi 94, sesuai dengan analisis nilai kompetensi pengetahuan IPA siswa pada kelompok kontrol. rekapitulasi data hasil posttestkelompok eksperimen dan kelompok kontrol disajikan pada tabel berikut.

Hasil perolehan rata-rata kelompok eksperimen dan kelompok kontrol memiliki perbedaan sebesar 10,6. Dengan demikian, terdapat pengaruh kompetensi pengetahuan IPA antara siswa kelas V di SD Gugus II Kuta Utara tahun pelajaran 2017/2018 yang dibelajarkan menggunakan model discovery learning berbantuan lingkungan dan siswa yang dibelajarkan menggunakan pembelajaran konvensional.

\section{Pembahasan}

Model discovery learning berbantuan lingkungan ini berpengaruh signifikan terhadap kompetensi pengetahuan IPA siswa. Hal ini didukung secara empiris melalui eksperimen yang telah dilakukan. Berdasarkan hasil temuan kedua kelompok yang memiliki pengetahuan awal yang setara kemudian setelah diberikan perlakuan, terdapat perbedaan yang signifikan. Perbedaan dipengaruhi oleh pelaksanaan proses pembelajaran pada kelompok eksperimen dan kelompok kontrol. Pembelajaran pada muatan materi IPA pada tema 8 Lingkungan Sahabat Kita di kelompok eksperimen dan kelompok kontrol menerapkan pendekatan saitifik. Namun, perbedaan hasil kompetensi pengetahuan IPA siswa yang signifikan antara kelompok eksperimen dan kelompok kontrol disebabkan adanya perlakuan pada 
kegiatan pelaksanaan pembelajaran berlangsung yaitu dengan model discovery learning berbantuan lingkungan.

Kegiatan pembelajaran dengan model discovery learning memiliki langkah-langkah, yaitu persiapan, pelaksanaan dan penilaian. Pada langkah persiapan seorang guru mempersiapkan segala sesuatunya dengan baik dan optimal. Pada tahap ini, guru harus menentukan tujuan pembelajaran terlebih dahulu sesuai dengan ketercapaian materi yang dibelajarkan dan sesuai dengan karakteristik siswa, memilih materi pembelajaran untuk siswa, menentukan topik bahasan yang dibahas pada pelaksanaan pembelajaran, mengembangkan materi-materi untuk siswa dan media atau sumber belajar, melakukan penilaian proses dan hasil belajar. Pada tahap pelaksaan, baik guru maupun siswa sama-sama berperan aktif dalam kegiatan proses pembelajaran. Pada tahap ini ada beberapa langkah, yaitu rangsangan/stimulasi, identifikasi masalah, pengumpulan data, pengolahan data, pembuktian dan menarik kesimpulan. Pada langkah rangsangan/ stimulus, guru pada awal pembelajaran memberikan beberapa pertanyaan maupun infromasi kepada siswa untuk memberikan tanggapan, tetapi pada tahap awal ini hanya satu dua siswa yang berani untuk mengeluarkan. Pada pembelajaran berikutnya, mulai beberapa siswa mengeluarkan pendapatnya. Langkah identifikasi masalah, pada langkah ini, guru memberikan kesempatan untuk siswa bertanya mengenai tema pembelajaran hari itu dan mendiskusikan jawaban ataupun solusinya bersama kelompok. Langkah selanjutnya pengumpulan data, siswa ditugaskan untuk melakukan pengamatan dan mengumpulkan informasi/data melalui buku dan lingkungan sekitarnya terkait dengan tugas dan tujuan pembelajaran. Langkah pengolahan data, siswa mengolah data yg telah didapat dan berdikusi bersama kelompoknya menyusunnya dalam sebuah tugas kelompok. Selanjutnya langkah pembuktian dimana siswa mengkomunikasikan hasil diskusi masing-masing kelompok. Pada langkah terakhir menarik kesimpulan, siswa dan guru menarik suatu kesimpulan atau garis besar bahasan yang menjadi bahas diskusi yang telah siswa kerjakan. Tahap terakhir yakni penilaian, guru menyusun penilaian proses dan hasil belajar dan melakukan evaluasi pada akhir pembelajaran.

Pada kelompok eksperimen, kegiatan pembelajaran dalam muatan materi IPA yang menggunakan model discovery learning berbantuan lingkungan berjalan dengan optimal dan kondusif. Hal ini disebabkan oleh model discovery learning berbantuan lingkungan merupakan inovasi dan upaya dalam menciptakan suasana belajar yang aktif dan lebih bermakna bagi siswa. Model discovery learning berbantuan lingkungan juga memiliki beberapa keunggulan atau kelebihan salah satunya siswa dapat memperkuat konsep pembelajaran dari percobaan yang dilakukan baik secara berkelompok maupun individu. Selain penggunaan model discovery learning dapat dipadukan atau dibantu dengan lingkungan baik sebagai media atau sumber belajar dan siswa memperoleh pengetahuannya secara langsung.

Berbeda pada kelompok kontrol, kegiatan pembelajaran konvensional yang dimana cara mengajar guru yang ceramah dan bekerja dalam kelompok berjalan kurang optimal. Hal ini disebabkan siswa yang kurang mampu mengaitkan antar materi pada muatan-muatan materi yang ada pada suatu tema dan mendengarkan ceramah dari guru menciptakan suasana yang kurang menarik bagi siswa. Pembelajaran yang kurang variasi dapat menciptakan kebosanan bagi siswa.

Pembelajaran dengan model discovery learning berbantuan lingkungan pada muatan materi IPA memberikan kesempatan yang lebih luas kepada siswa untuk membangun pengetahuannya melalui berpikir dan percobaan yang dilakukan. Dengan demikian, perbedaan kompetensi pengetahuan IPA dapat terlihat dari langkah pembelajaran yang dilakukan pada kedua kelompok tersebut, hasil analisis uji hipotesis, dan nilai rata-rata kelompok siswa yang mengikuti pembelajaran menggunakan model discovery learning berbantuan lingkungan dan kelompok siswa yang mengikuti pembelajaran konvensional.

Hasil temuan pada penelitian ini memiliki persamaan dengan penelitian sebelumnya yang relevan dan memperkuat hasil penelitian yang diperoleh, hal tersebut didukung hasil penelitian yang dilakukan oleh Putrayasa (2014) selanjutnya penelitian yang dilakukan oleh Malihatul (2016) serta penelitian yang dilakuan oleh M. Lamasai (2014).

Dengan demikian, pembelajaran menggunakan model discovery learning berbantuan lingkungan pada penelitian ini memiliki keunggulan yakni dapat menciptakan suasana aktif dan lebih bermakna bagi siswa karena dapat membangun pengetahuannya melalui percobaan yang dilakukan dan berperan aktif di dalam kelas serta guru sebagai fasilitator dan pembimbing dalam pembelajaran.

\section{Simpulan dan Saran}

Kompetensi pengetahuan IPA kelompok siswa yang dibelajarkan melalui model discovery learning berbantuan lingkungan pada siswa kelas V SD Negeri Gugus II Kuta Utara Tahun Ajaran 2017/2018 
memperoleh rata-rata (mean) 84,63, varian 111,73 dan standar deviasi 10,57.Rata-rata (mean) 84,63 dikonversikan ke dalam kriteria PAP berada pada kriteria baik.

Kompetensi pengetahuan IPA kelompok siswa yang dibelajarkan melalui pembelajaran konvensional pada siswa kelas V SD Negeri Gugus II Kuta Utara 2017/2018 memperoleh rata-rata (mean) 74,03, varian 124,91 dan standar deviasi 11,18. Rata-rata (mean) 74,03 dikonversikan ke dalam kriteria PAP berada pada kriteria cukup.

Hasil perhitungan uji $\mathrm{t}$ diperoleh $\mathrm{t}_{\text {hitung }}=3,926$. Kemudian pada taraf signifikan $5 \%$ dan $\mathrm{dk}=\mathrm{n} 1+$ $n 2-2(32+33-2=63)$ diperoleh $t_{\text {tabel }}=1,998$. Maka $t_{\text {hitung }}>t$ tabel yaitu $3,926>1,998$. Jadi, Ho ditolak ini berarti terdapat perbedaan yang signifikan kompetensi pengetahuan IPA kelompok siswa yang dibelajarkan melalui model discovery learning berbantuan lingkungan dan kelompok siswa yang dibelajarkan melalui pembelajaran konvensional pada kelas V SD Negeri Gugus II Kuta Utara Tahun Ajaran 2017/2018. Dapat dikatakan bahwa model discovery learning berbantuan lingkungan berpengaruh terhadap kompetensi pengetahuan siswa kelas V SD Negeri Gugus II Kuta Utara Tahun Ajaran 2017/2018.

Ada beberapa saran yang dapat diajukan berdasarkan temuan dan kajian penelitian ini kepada (1) Siswa, berdasarkan temuan penelitian, disarankan kepada siswa agar memanfaatkan kesempatan yang difasilitasi guru dengan berpartisipasi aktif dalam kegiatan pembelajaran. (2) Guru, berdasarkan temuan penelitian yang diperoleh, disarankan kepada guru agar lebih inovatif untuk menggunakan model pembelajaran agar menciptakan suasana belajar yang aktfi dan kondusif serta menyenangkan bagi siswa dalam menerima materi pembelajaran. (3) Sekolah, berdasarkan temuan penelitian, disarankan kepada kepala sekolah agar dapat menggunakan hasil penelitian ini sebagai pendukung sumber belajar guru dalam meningkatkan kualitas pembelajaran dengan menciptakan pembelajaran yang menggembirakan di sekolah sehingga sekolah mampu menghasilkan siswa yang memiliki output berkualitas. (4) Peneliti Lain , berdasarkan temuan penelitian, disarankan kepada peneliti lain agar hasil penelitian ini digunakan sebagai referensi untuk melaksanakan penelitian selanjutnya atau menemukan inovasi kegiatan pembelajaran lainnya yang bermakna bagi siswa.

\section{Daftar Rujukan}

Agung, A.A. Gede. 2014. Metodologi Penelitian Pendidikan. Yogyakarta : Aditya Media Publishing.

Amallia Nugrahaeni, I Wayan Redhana, I Made Arya Kartawan.2017. "Penerapan Model Pembelajaran Discovery Learning Untuk Meningkatkan Kemampuan Berpikir Kritis Dan Hasil Belajar Kimia". Jurnal Pendidikan Kimia Indonesia Vol 1, No 1 (2017).

Arikunto, Suharsimi. 2015. Dasar-dasar Evaluasi Pendidikan. Jakarta : PT. Bumi Aksara

Barus, Ira Wati. 2017. "Peningkatan Keterampilan Menulis Cerpen Melalui Penerapan Model Pembelajaran Discovery Learning Dengan Bantuan Media Film Pendek Pada Siswa Kelas IX.13 SMP Negeri 2 Singaraja' Journal of Education Action Research Vol 2, No 2 (2018): May 2017.

Husamah. 2013. Pembelajaran diluar Kelas Outdoor Learning. Jakarta : Prestasi Pustakaraya.

Kurniasih, Imas dan Berlin Sani. 2014.SuksesMengim- plementasikan Kurikulum 2013. Yogyakarta : Kata Pena.

M. Lamasai, Muzria. 2014. "Pemanfaatan Lingkungan Alam Sekitar Sebagai Sumber Belajar Dalam Meningkatkan Hasil Belajar IPA Siswa Kelas III SDN 10 Gadung". Vol. 5 No. 3.

Malihatul Aini, Isna. 2016. “Pengaruh Penggunaan Model Pembelajaran Discovery Learning (DL) Terhadap Hasil Belajar Tematik Siswa Kelas V SD Negeri 2 Labuhan Ratu Bandarlampung Tahun Pelajaran 2014/2015". (diakses pada tanggal 6 Maret 2018, pukul 17.00)

N, Budiman. N. 2012. Etika Profesi Guru. Yogyakarta : Mentari Pustaka.

Permendikbud. 2014. "Peraturan Menteri Pendidikan dan Kebudayaan Republik Indonesia Nomor 57 Tahun 2014 Tentang Kurikulum 2013 Sekolah Dasar/Madrasah Ibtidaiyah Lampiran III". Jakarta : Kemendikbud. 
Putra . Komang Wisnu Baskara \& I Made Agus Wirawan, Gede Aditra Pradnyana.2017. "Pengembangan EModul Berbasis Model Pembelajaran Discovery Learning Pada Mata Pelajaran "Sistem Komputer" Untuk Siswa Kelas X Multimedia SMK Negeri 3 Singaraja". Jurnal Pendidikan Teknologi dan Kejuruan Vol 14, No 1 (2017): Edisi Januari 2017.

Putrayasa, I Made. 2014. “ Pengaruh Model Pembelajaran Discovery Learning dan Minat Belajar Terhadap Hasil Belajar IPA Siswa”. Jurnal Mimbar PGSD Universitas Pendidikan Ganesha, Volume 2.

Rismayani , Ni Luh. Penerapan Model Pembelajaran Discovery Learning Untuk Meningkatkan Hasil Belajar Pkn Siswa. Jurnal Pendidikan Kewarganegaraan Undiksha Vol 1, No 2 (2013).

Sani, Ridwan Abdullah. 2014. Pembelajaran Saintifik. Jakarta : Bumi Aksara.

Samatowa, Usman. 2016. Pembelajaran IPA di Sekolah Dasar. Jakarta : PT. Indeks.

Setyosari, H. Punaji. 2013. Metode Penelitian Pendidikan dan Pengembangan. Jakarta : Prenadamedia Group.

Sugiyono. 2016. Metode Penelitian Kuantitatif, Kualitatif dan R\&D. Bandung : Alfabeta.

Wisudawati, Asih Widi dan Eka Sulistyowati. 2014. Metodologi Pembelajaran IPA. Jakarta : PT. Bumi Aksara. 